\title{
HUBUNGAN ANTARA KESIAPAN BELAJAR DENGAN KOMPETENSI INTI PENGETAHUAN BAHASA INDONESIA PADA SISWA KELAS V SD GUGUS LETKOL WISNU DENPASAR UTARA TAHUN PELAJARAN 2017/2018
}

\author{
Ni Pt Trisna Hendrayani ${ }^{1}$, I Wyn Sujana ${ }^{2}$, Ni Nym Ganing ${ }^{3}$ \\ 1,2,3 Jurusan Pendidikan Guru Sekolah Dasar \\ Universitas Pendidikan Ganesha \\ Singaraja, Indonesia \\ e-mail: putu.trisna.hendrayani@undiksha.ac.id ${ }^{1}$,iwayan.sujana@undiksha.ac.id ${ }^{2}$, \\ nyoman.ganing@undiksha.ac.id ${ }^{3}$
}

\begin{abstract}
Abstrak
Penelitian ini bertujuan untuk mengetahui hubungan antara kesiapan belajar dengan kompetensi inti pengetahuan bahasa Indonesia pada siswa kelas V SD Gugus Letkol Wisnu Denpasar Utara Tahun Pelajaran 2017/2018. Jenis penilitian ini adalah penelitian ex post facto dengan korelasi yang bersifat asimetris.Populasi dari penelitian ini merupakan seluruh siswa kelas $\mathrm{V}$ yang berada di SD Gugus Letkol Wisnu Denpasar Utara Tahun Pelajaran 2017/2018 yang memiliki populasi 340 orang.Penentuan sampel menggunakan teknik proporsional random sampling dengan taraf kesalahan $5 \%$ dan diperoleh banyak sampel dari populasi adalah 172 orang. Data diperoleh melalui hasil dari penyebaran angket/kuesioner kesiapan belajar dan kompetensi inti pengetahuan bahasa Indonesia diperoleh dari pencatatan dokumen nilai ulangan akhir semester kompetensi inti bahasa Indonesia kelas V SD Gugus Letkol Wisnu, Denpasar Utara pada semester 1. Sebagai uji prasyarat adalah uji normalitas sebaran data.Setelah seluruh uji prasyarat terpenuhi, analisis statistik yang digunakan pada penelitian ini adalah uji hipotesis menggunakan analisis korelasi product moment.Berdasarkan hasil analisis maka $r_{x y}$ hitung $=0,818$. Pada taraf signifikansi $5 \%$ dengan $\mathrm{n}=172$, maka diperoleh $r_{x y}$ tabe $=$ 0,148 . Dapat dinyatakan bahwa $r_{x y}$ hitung $=0,818>r_{x y}$ tabe $=0,148$ maka dapat diartikan bahwa $\mathrm{H}_{0}$ yang berbunyi tidak terdapat hubungan yang signifikan antara kesiapan belajar dengan kompetensi inti pengetahuan bahasa Indonesia pada siswa kelas V SD Gugus Letkol Wisnu Denpasar Utara ditolak hal ini berarti Ha diterima. Jadi dapat disimpulkan bahwa terdapat hubungan yang signifikan antara kesiapan belajar dengan kompetensi inti pengetahuan bahasa Indonesia pada siswa kelas V SD Gugus Letkol Wisnu Denpasar Utara Tahun Pelajaran 2017/2018, dengan arah korelasi positif, artinya semakin tinggi kesiapan belajar maka semakin tinggi pula kompetensi inti pengetahuan bahasa Indonesia.
\end{abstract}

Kata kunci: kesiapan belajar, kompetensi inti pengetahuan,bahasa Indonesia.

\section{Abstract}

This study was intended to determine the relationship between the readiness of learning with the core competence of Indonesian language knowledge of the $V$ grade students of SD Gugus Letkol Wisnu North Denpasar in Academic Year 2017/2018. The type of this research was ex post facto research with asymmetric correlation. The population of this study was all students of $V$ grade students which located at SD Gugus Letkol Wisnu North Denpasar in Academic Year 2017/2018 which has population of 340 students. The determination of the sample used proportional random sampling technique with 5\% error rate and obtained many samples from the population were 172 students. The data which obtained through the results of the questionnaires about the readiness of learning and the core competence of Indonesian language knowledge were obtained from recording documents value of the end semester of the core competence of Indonesian language knowledge of the $V$ grade students of SD Gugus Letkol Wisnu North Denpasar in semester 1. As the test was a normality test data distribution. After all the prerequisite tests were fulfilled, statistical analysis used in this research was hypothesis test which used product moment correlation analysis. Based on the results of the analysis, then $r_{x y \text { coun }} t=0.818$. At the significance level of $5 \%$ with $n=172$, then obtained $r_{x y}$ table $=0,148$.I could be stated that $r_{x y}$ count $=0,818>r_{x y}$ table $=0,148$, hence it can be interpreted that $\mathrm{HO}$ which reads there was no significant correlation between the readiness of learning with core competence of Indonesian language knowledge of the $V$ grade students of SD Gugus Letkol Wisnu North Denpasar rejected this mean Ha accepted. Therefore, it can be concluded that there was a 
significant relationship between the readiness of learning with the core competence of Indonesian language knowledge of the V grade students of SD Gugus Letkol Wisnu North Denpasar in Academic Year 2017/2018, with a positive correlation direction, it means the higher the readiness of learning so that the higher the core competence of Indonesian language knowledge.

Keywords : readiness of learning, core competence, Indonesian language knowledge.

\section{Pendahuluan}

Pelaksanaan pembelajaran dalam krurikulum 2013 guru harus memiliki strategi.Strategi pembelajaran yang digunakan oleh seorang guru bertujuan memfasilitasi siswa untuk mencapai kompetensi yang telah dirancang dalam kurikulum sehingga setiap siswa nantinya mampu belajar mandiri sepanjang hayatnya.

Bagi siswa belajar merupakan suatu proses perubahan yaitu perubahan tingkah laku sebagai hasil dari interaksi dengan lingkungannya dalam memenuhi kebutuhan hidupnya (Slameto, 2010:2). Perubahan-perubahan tersebut terjadi secara nyata dalam seluruh aspek afektif, kognitif, dan psikomotor.Perubahan yang terjadi pada siswa berlangsung secara berkesinambungan, tidak secara statis. Satu perubahan yang terjadi menyebabkan perubahan berikutnya dan berguna bagi kehidupan ataupun proses belajar berikutnya.

Pada dasarnya aspek kognitif merupakan aspek yang mendominasi dalam proses belajar siswa. Menurut Sutikno (2009) salah satu faktor psikologi yang mempengaruhi belajar siswa adalah kesiapan belajar.Kesiapan belajar adalah kondisi siswa yang siap menerima pelajaran dari guru, dan berusaha merespons atas pertanyaan-pertanyaan yang telah diberikan oleh guru. Untuk dapat memberi jawaban yang benar tentunya siswa harus mempunyai pengetahuan dengan cara membaca atau mempelajarai materi yang diajarkan oleh guru selain itu kesiapan kondisi fisik, mental dan emosioal siswa juga dapat mempengaruhi bagaimana siswa itu siap menerima pelajaran yang diajarkan oleh guru. Seseorang baru dapat belajar tentang sesuatu apabila dalam dirinya sudah terdapat kesiapan di dalam dirinya untuk mempelajari sesuatu.Siap belajar diartikan bahwa pada saat membuka pembelajaran siswa sudah siap menerima pelajaran pada saat itu.Dengan kondisi seperti ini maka pembelajaran mudah dilanjutkan sesuai perencanaan yang telah ditentukan guru.

Namun pada kenyataan, kesiapan belajar siswa belum dikondisikan oleh guru untuk mengembangkan potensi siswa dalam pelajaran bahasa Indonesia. Pada saat pelajaran bahasa Indonesia siswa belum siap untuk mengikuti pelajaran hal ini nampak ketika guru membuka pelajaran siswa belum mempersiapkan buku pelajaran bahasa Indonesia dan juga siswa sering merasa bosan dan mengantuk ketika kegiatan membaca dan mendengarkan. Untuk memahami materi pembelajaran bahasa Indonesia harus memiliki kesiapan kondisi fisik, mental dan emosional mengingat pelajaran bahasa Indonesia tidak hanya dipahami melainkan juga harus dihayati.

Sebelum memulai pelajaran, guru harus terlebih dahulu memperhatikan atau mempersiapkan siswa untuk belajar melalui apersepsi, jika siswa sudah siap melaksanakan pelajaran bahasa Indonesia maka siswa mampu mengikuti pelajaran bahasa Indonesia. Selain mengkondisikan siswa guru juga harus tahu bagaimana kondisi fisik, mental, dan emosional siswa, sehingga potensi yang ada pada dalam diri siswa dapat berkembang secara optimal. Dilihat dari hal tersebut pentingnya kesiapan siswa dalam belajar untuk mengikuti pelajaran bahasa Indonesia yang nantinya akan berdampak pada kompetensi inti pengetahuan bahasa Indonesia siswa.

Adapun tujuan penelitian ini yaitu untuk mengetahui hubungan yang signifikan antara kesiapan belajar dengan kompetensi inti pengetahuan bahasa Indonesia pada siswa Kelas $\mathrm{V}$ SD Gugus Letkol Wisnu Denpasar Utara Tahun Pelajaran 2017/2018. 


\section{Metode}

Penelitian ini menggunakan rancangan penelitian ex post facto. Menurut Kerlinger (dalam Emzir, 2011:119) ex post facto adalah penyelidikan empiris yang sistematis dimana ilmuan tidak mengendalikan variabel bebas secara langsung karena eksistensinya dari variabel tersebut telah terjadi atau karena variabel tersebut pada dasarnya tidak dapat dimanipulasi, kesimpulan tentang adanya hubungan di antara variabel tersebut dibuat berdasarkan perbedaan yang mengiringi variabel bebas dan variabel terikat, tanpa interpensi langsung."Korelasi adalah suatu bentuk analisis data dalam penelitian yang bertujuan untuk mengetahui kekuatan atau bentuk arah hubungan di antara dua variabel atau lebih, dan besarnya pengaruh yang disebabkan oleh variabel satu (variabel bebas) terhadap variabel lainnya (variabel terikat)" (Siregar, 2015:200).Dapat disimpulkan bahwa korelasi merupakan dua buah variabel yaitu varibel bebas dan variabel terikat yang memiliki hubungan.

Penelitian ini menggunakan dua variabel, yaitu variabel bebas (independent) dan variabel terikat (dependent). Sebagai variabel bebasnya adalah kesiapan belajar (X) dan variabel terikatnya adalah penguasaan kompetensi inti bahasa Indonesia kelas $V(Y)$.

Setiap penelitian didasarkan atas adanya masalah dan objek yang diteliti. Antara satu penelitian dangan penelitian lainnya memiliki subjek yang berbeda-beda bergantung pada konteks penelitian.Populasi merupakan salah satu dari subjek penelitian."Populasi adalah wilayah generalisasi yang terdiri atas obyek/subjek yang mempunyai kualitas dan karakteristik tertentu yang ditetapkan oleh peneliti untuk dipelajari dan kemudian ditarik kesimpulan" (Sugiyono, 2009:117).Hal ini sependapat dengan Arikunto (2010) populasi adalah keseluruhan subjek penelitian, apabila seseorang ingin meneliti semua elemen yang ada dalam wilayah penelitian, maka penelitiannya merupakan penelitian populasi. Dapat disimpulkan bahwa pengertian populasi adalah keseluruhan elemen/ individu yang dijadikan subjek yang mempunyai kualitas dan karakteristik tertentu yang ditetapkan oleh peneliti untuk dipelajari dan kemudian ditarik kesimpulannya untuk dijadikan perhatian dan kajian dalam penelitian.Populasi dalam penelitian ini adalah seluruh siswa kelas V SD Gugus Letkol Wisnu, Denpasar Utara Tahun Pelajaran 2017/2018 dengan 7 SD Negeri yang berjumlah 340 siswa.

Penelitian ini mengambilan sampel dari populasi menggunakan teknik sampling untuk menentukan sampel yang akan digunakan.Dalam penelitian banyak terdapat teknik sampling yang digunakan mengambil sempel, namun pada penelitian ini, teknik yang digunakan dalam mengambil sempel adalah teknik proporsional random sampling.Menurut Arikunto (2010) teknik pengambilan sampel proporsional sampel ini dilakukan untuk menyempurnakan penggunaan teknik sampel berstrata atau sempel wilayah agar sampel tersebut bersifat representative.Random adalah pengambilan anggota sampel dari populasi secara acak (Musfiquon, 2012).

Salah satu menentukan sampel dapat dilihat pada tabel Issac and Michel.Pada tabel Issac and Michel dijelaskan tentang besarnya sampel yang diambil dari populasi dengan tingkat kesalahan 1\%, 5\%, dan 10\% (Sugiyono, 2014).Sesuai dengan tabel tersebut, pada jenjang pendidikan digunakan tingkat kesalahan 5\%. Dilihat pada tabel Issac and Michel jadi jumlah sampel yang diambil dengan tingkat kesalahan 5\% adalah 172 orang siswa.Jumlah Sampel Siswa Kelas V SD Gugus Letkol Wisnu yaitu.

Suatu penelitian sebagai suatu cara ilmiah dalam menyelesaikan masalah, yang akan berhubungan dengan instrument pengumpulan data. Menurut Sanjaya (2013:247) menerangkan bahwa "tanpa instrument yang tepat, penelitian tidak akan menghasilkan suatu yang diharapkan". Pengumpulan data kesiapan belajar dikumpulkan dengan angket/kuesioner yang akan disebarkan pada siswa kelas V SD Gugus Letkol Wisnu, Denpasar Utara adapun indikator kesiapan belajar yang akan diukur yaitu kondisi fisik, kondisi mental, kondisi emosional, kebutuhan, pengetahuan. Sebelum penyebaran angket/kuesioner, angket/kuesioner terlebih dahulu diuji coba.

Pada penelitian ini untuk menguji kevalidan butir angket penelitian menggunakan validitas logis.Ada dua macam validitas logis yang dapat dicapai oleh sebuah instrument yaitu validitas isi dan validitas konstrak. Sedangkan pengumpulan data kompetensi inti 
pengetahuan bahasa Indonesia dikumpulkan dengan pencatatan dokumen yaitu melalui daftar nilai UAS kompetensi inti bahasa Indonesia kelas V SD Gugus Letkol Wisnu, Denpasar Utara semester 1.

Dalam penelitian ini metode penelitian yang digunakan adalah metode analisis statistik deskriptif dan metode analisis statistik inferensial. Melalui metode analisis deskriptif kuantitatif pada penelitian ini cara yang dilakukan untuk pengolahan datanya adalah dengan menerapkan rumus mean (rata-rata), median, dan standar deviasi. Metode analisis statistik inferensial yaitu menguji hipotesis korelasi/hubungan antara kesiapan belajar dengan kompetensi inti pengetahuan bahasa Indonesia.

Untuk memenuhi prasyarat uji hipotesis, maka dierlukan prasyarat analisis yaitu uji normalitas. Kreteria yang digunakan adalah dengan membandingkan nilai $\mathrm{X}_{\text {tabel }}^{2}$ dengan $\mathrm{X}^{2}$ hitung pada taraf signifikan $5 \%$ dengan ketentuan $\mathrm{X}^{2}{ }_{\text {hitung }} \leq \mathrm{X}^{2}$ tabel, maka Ho diterima dan $\mathrm{Ha}$ ditolak yang berarti data berdistribusi normal.

Setelah diketahui data berdistribusi normal dilanjutkan menganalisis dengan menggunakan teknik analisis korelasi Product Moment. Menurut Agung (2016:125) "teknik korelasi Product Moment berfungsi untuk menghitung koefisien korelasi antara variabel bebas interval (skor) dengan variabel terikat interval (skor) lainnya".

\section{Hasil dan Pembahasan}

Hasil penelitian ini memaparkan mengenai data kesiapan belajar sebagai variabel bebas $(X)$ dan data kompetensi inti pengetahuan bahasa Indonesia sebagai variabel terikat (Y) yang ditampilkan grafik.

Dari data kesiapan belajar dapat dilihat dalam bentuk grafik berikut.

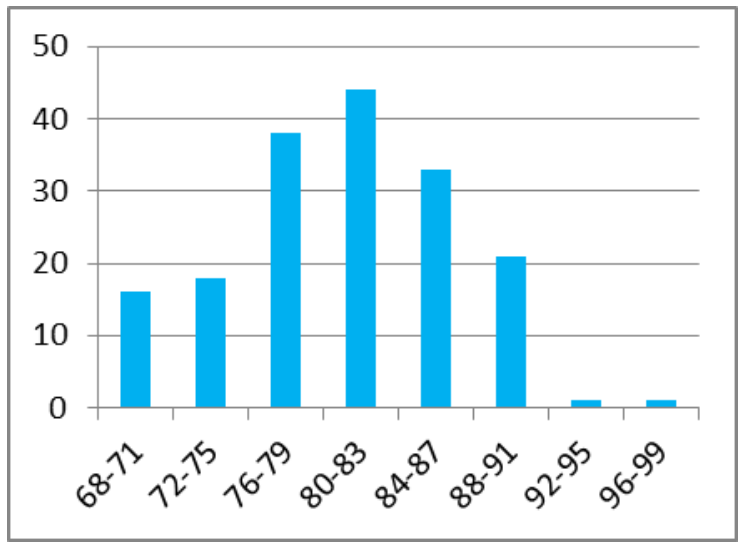

Gambar 1. Gambar Histogram Data Kesiapan Belajar

Data kesiapan belajar dapat diketehui bahwa frekuensi nilai terbanyak terdapat pada interval ke-4, rerata dari kesiapan belajar siswa adalah 80,56 . Tingkat perkembangan kognitif yang diperoleh siswa hasilnya dikonversikan dengan cara membandingkan angka rata-rata dengan kriteria penilaian acuan patokan (PAP) skala sebagai berikut.

\section{Pedoman Konversi PAP Skala Lima tentang Kesiapan Belajar} (Sumber: Agung, 2014)

\section{Persentase Kesiapan Belajar}

$90-100$

80-89

$65-79$

$55-64$

\section{Kriteria Kesiapan Belajar}

\author{
Sangat Tinggi \\ Tinggi \\ Cukup Tinggi \\ Rendah
}




\section{0-54 Sangat Rendah}

Nilai tersebut berada pada nilai PAP rentangan 80-89.Maka dapat disimpulkan bahwa kesiapan belajar siswa kelas V SD Gugus Letkol Wisnu Denpasar Utara tergolong tinggi.

Dari data kesiapan belajar dapat dilihat dalam bentuk grafik berikut.

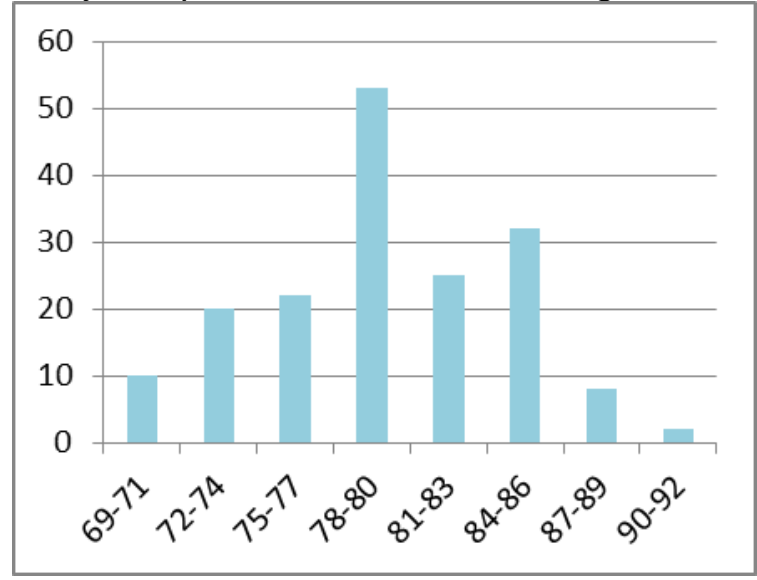

Gambar 2. Gambar Histogram Data Nilai Ulangan Akhir Semester 1 Kompetensi Inti Pengetahuan Bahasa Indonesia

Data nilai ulangan akhir semester 1 kompetensi inti pengetahuan bahasa Indonesia dapat diketahui bahwa frekuensi nilai terbanyak terdapat pada interval ke-4, rerata dari kategori kompetensi inti pengetahuan bahasa Indonesia siswa adalah 79,43 Tingkat perkembangan kognitif yang diperoleh anak hasilnya dikonversikan dengan cara, membandingkan angka rata-rata dengan kriteria penilaian acuan patokan (PAP) skala 5 sebagai berikut.

\section{Pedoman Konversi PAP Skala Lima tentang Kompetensi Inti Pengetahuan Bahasa Indonesia (Sumber: Agung, 2014)}

\section{Persentase Kompetensi Inti$$
\text { Pengetahuan }
$$ Bahasa Indonesia}

90-100

80-89

65-79

55-64

0-54

\section{Kriteria Kompetensi Inti$$
\text { Pengetahuan }
$$ Bahasa Indonesia}

\author{
Sangat Baik \\ Baik \\ Cukup Baik \\ Kurang Baik \\ Sangat Kurang \\ Baik
}

Nilai tersebut berada pada nilai PAP rentang 65-79. Maka dapat disimpulkan bahwa kompetensi inti pengetahuan bahasa Indonesia siswa kelas V SD Gugus Letkol Wisnu Denpasar Utara tergolong cukup baik. Langkah selanjutnya adalah uji prasyarat yaitu Uji Normalitas kesiapan belajar dan kompetensi inti pengetahuan bahasa Indonesia pada siswa kelas V SD Gugus Letkol Wisnu Denpasar Utara menggunakan teknik uji Chi-Kuadrat (x2).

Hasil uji normalitas kesiapan belajar yaitu berdasarkan analisis diperoleh $x_{\text {hitung }}^{2} 7,14$, dan menggunakan taraf signifikan $5 \%$ dengan menggunakan derajat kebebasan yaitu: 
$\mathrm{dk}$

$$
\begin{aligned}
& =\mathrm{k}-1 \\
& =6-1=5
\end{aligned}
$$

Jadi, menggunakan derajat kebebasan pada kolom ke 5 , maka diperoleh $x_{\text {tabel }}^{2}=11,07$. Hal ini berarti $X^{2}$ hitung $=7,14<X_{\text {tabel }}^{2}=11,07$. Hal ini berarti $\mathrm{H}_{0}$ diterima, sehingga dapat disimpulkan bahwa sebaran data berdistribusi normal.

Hasil uji normalitas kompetensi inti pengetahuan bahasa Indonesia pada siswa kelas V SD Gugus Letkol Wisnu Denpasar Utara yaitu berdasarkan analisis diperoleh $x^{2}$ hitung $=7,61$, dan menggunakan taraf signifikan 5\% dengan menggunakan derajat kebebasan yaitu:

$\mathrm{dk} \quad=\mathrm{k}-1$

$$
=6-1=5
$$

Jadi, menggunakan derajat kebebasan pada kolom ke 5 , maka diperoleh $x_{\text {tabel }}^{2}=11,07$. Hal ini berarti $x_{\text {hitung }}^{2}=7,61<x_{\text {tabel }}^{2}=11,07$. Hal ini berarti $\mathrm{H}_{0}$ diterima, sehingga dapat disimpulkan bahwa sebaran data berdistribusi normal.

Setelah melalui uji normalitas dan data berdistribusi normal maka dilanjutnya dengan uji hipotesis Uji hipotesis yang dilakukan adalah uji hipotesis dengan teknik menggunakan analisis product moment (variabel $\mathrm{X}$ dengan $\mathrm{Y}$ ). Pengujian hipotesis, perlu adanya hipotesis alternative $(\mathrm{Ha})$, untuk analisis data akan dirumuskan juga hipotesis nol $\left(\mathrm{H}_{0}\right)$. Karena dalam statistika, yang diuji adalah hipotesis nol $\left(\mathrm{H}_{0}\right)$.

Adapun hipotesis yang akan dirumuskan sebagai berikut.

$\mathrm{H}_{0} \quad$ : tidak terdapat korelasi yang signifikan antara kesiapan belajar dengan

kompetensi inti pengetahuan bahasa Indonesia pada siswa kelas V SD Gugus Letkol Wisnu Denpasar utara tahun pelajaran 2017/2018. Hasil analisis product moment dapat dilihat pada rumus sebagai berikut.

$$
r_{x y}=\frac{N \sum X Y-\left(\sum X\right)\left(\sum Y\right)}{\sqrt{\left[N \sum X^{2}-\left(\sum X\right)^{2}\right]\left[N \sum Y^{2}-\left(\sum Y\right)^{2}\right]}}
$$

Untuk uji signifikansi koefisien korelasi, digunakan nilai tabel product moment $(\mathrm{r}$ ) untuk $\mathrm{n}$ $=172$, pada taraf signifikansi $5 \%$ diperoleh nilai $r_{x y}$ tabel adalah 0,148 sedangkan $r_{x y}$ hitung diperoleh hasil 0,818. Maka dapat dinyatakan $r_{x y h i t u n g}>r_{x y}$ tabelyaitu 0,818 $>0,148$ ini berarti nilai $r_{\text {xyhitung }}$ signifikan dengan nilai 0,818.

Dari paparan analisis sebelumnya dapat dinyatakan $\mathrm{H}_{0}$ yang berbunyi tidak terdapat korelasi yang signifikan antara kesiapan belajar dengan kompetensi inti pengetahuan bahasa Indonesia pada siswa kelas V SD Gugus Letkol Wisnu Denpasar Utara Tahun Pelajaran 2017/2018 ditolak, dan $\mathrm{H}_{\mathrm{a}}$ diterima. Hal ini menunjukan bahwa terjadi hubungan yang kuat antara kesiapan belajar dengan kompetensi inti pengetahuan bahasa Indonesia pada siswa kelas V SD Gugus Letkol Wisnu Denpasar Utara Tahun Pelajaran 2017/2018. Sedangkan arah korelasi, memiliki arah korelasi yang positif berarti semakin tinggi kesiapan belajar maka semakin meningkat kompetensi inti pengetahuan bahasa Indonesia pada siswa.

Berdasarkan hasil analisis yang diperoleh sebelumnya $r_{x y}$ hitung $>r_{x y}$ tabel, sehingga terdapat hubungan yang signifikan antara kesiapan belajar dengan kemampuan pemecahan masalah kompetensi inti pengetahuan bahasa Indonesia Kelas V SD Gugus Letkol Wisnu, Denpasar Utara Tahun Pelajaran 2017/2018.Berdasarkan uraian tersebut dapat diinterpretasi, bahwa rata-rata siswa yang mempunyai kesiapan belajar dapat memperoleh kompetensi inti pengetahuan bahasa Indonesia yang lebih tinggi daripada siswa yang tidak mempunyai kesiapan belajar.

Interpretasi di atas dapat diartikan bahwa, semakin tinggi kesiapan belajar membuat siswa lebih aktif dalam belajar sehingga dapat mempermudah siswa dalam mengkaitkan pengetahuan yang dimiliki oleh siswa dengan materipeajaran yang disampaikan oleh guru yang akhirnya mempengaruhi penguasaan kompetensi inti pengetahuan bahasa Indonesia siswa.Hal ini sesuai dengan pendapat Slameto (2010) salah satu faktor yang mempengaruhi hasil belajar siswa adalah kesiapan belajar.Kesiapan belajar faktor yang berasal daridalam diri siswa untuk mempersiapkan dirinya dalam menerima pelajaran. Hal ini sejalan dengan pendapat Mulyani (2013:Vol.2) mengatakan bahwa siswa yang tidak memiliki kesiapan 
dalam belajar cenderung menunjukan prestasi belajar rendah, sebaliknya siswa yang memiliki kesiapan dalam belajar cenderung menunjukan prestasi belajar yang tinggi. Serta pada penelitian Budiman (2017) kesiapan belajar adalah kondisi-kondisi yangmendahului kegiatan belajar itu sendiri, tanpakesiapan atau kesediaan ini, proses belajar tidak akan terjadi. Untuk dapat mengikuti pelajaran dengan baik tentu siswa harus mempunyai pengetahuan dengan cara membaca atau mempelajarai materi yang diajarkan oleh guru. Kesiapan kondisi fisik merupakan kondisi tubuh siswa yang siap untuk belajar, kondisi mental merupakan kondisi batin siswa untuk menjalankan tugas-tugas yang diberikan oleh guru dan kondisi emosioal merupakan kondisi perasaan siswa untuk mengikuti pelajaran. Jika semua pihak terkait (siswa, orang tua siswa, dan guru) memperhatikan kondisi-kondisi tersebut siswa akan siap menerima pelajaran yang diajarkan oleh guru. Seseorang baru dapat belajar tentang sesuatu apabila dalam dirinya sudah terdapat kesiapan untuk mempelajari sesuatu.Siswa yang memiliki kesiapan belajar lebih mudah mengkaitkan materi pelajaran yang dimiliki oleh siswa tersebut dengan materi pelajaran yang dipelajarinya disekolah.Kesiapan belajar siswa dapat diperhatikan dan dikondisikan dari pembukaan pembelajaran atau pada saat apersepsi.

Dari pendapat sebelumnya dapat disimpulkan bahwa siswa yang memiliki kesiapan belajar yang tinggi akan memiliki hasil belajar yang tinggi begitu juga sebaliknya siswa yang memiliki kesiapan belajar yang rendah akan memiliki hasil belajar yang rendah, maka sangat perlu diperhatikannya kesiapan belajar siswa karena akan mempengaruhi hasil belajar siswa itu sendiri.Pada penelitian ini diperoleh $r_{x y \text { hitung }}=0,818$ dengan $r_{x y \text { tabel }}=0,148$ yang berarti $r_{x y \text { hitung }}>r_{x y \text { tabel }}$. Hal ini sejalan dengan penelitian Mulyani dengan hasil nilai koefisien $r_{x y \text { hitung }}$ adalah 0,540 dengan $r_{x y \text { tabel }}=0,286$ yang berarti $r_{x y \text { hitung }}>r_{x y \text { tabel }}$. Hasil penelitian dapat disimpulkan ada korelasi positif antara kesiapan belajar dengan kompetensi inti pengetahuan bahasa Indonesia pada siswa kelas V SD Gugus Letkol Wisnu Tahun Pelajaran 2017/2018.

\section{Simpulan dan Saran}

Hasil analisis menunjukkan bahwa terdapat korelasi yang signifikan antara kesiapan belajar dengan kompetensi inti pengetahuan bahasa Indonesia pada siswa kelas $\mathrm{V}$ SD Gugus Letkol Wisnu Denpasar Utara Tahun Pelajaran 2017/2018. Kategori korelasi yang diperoleh termasuk korelasi sangat kuat antara kesiapan belajar dengan kompetensi inti pengetahuan bahasa Indonesia.Sedangkan arah korelasi adalah positif karena nilai $r$ positif, berarti semakin tinggi kesiapan belajar maka semakin tinggi pula kompetensi inti pengetahuan bahasa Indonesia.

Berdasarkan hasil analisis dengan menggunakan microsoft excel dan menghitung manual yang diperoleh $r_{x y}$ hitung $=0,818$ dengan $r_{x y}$ tabel $=0,148$ yang memiliki arti $r_{x y}$ hitung $>r_{x y}$ tabel, sehingga dapat disimpulkan terdapat hubungan yang signifikan antara kesiapan belajar dengan kompetensi inti pengetahuan bahasa Indonesia Kelas V SD Gugus Letkol Wisnu, Denpasar Utara Tahun Pelajaran 2017/2018 .

Berdasarkan uraian tersebut dapat diinterpretasikan, maka ini berarti rata-rata siswa yang memiliki kesiapan belajar dapat memperoleh kompetensi inti pengetahuan bahasa Indonesia yang lebih tinggi daripada siswa yang tidak memiliki kesiapan belajar. Jadi dapat disimpulkan bahwa antara kesiapan belajar dengan kompetensi inti pengetahuan bahasa Indonesia memiliki korelasi dengan arah positif pada kategori sangat kuat.

Adapun saran yang disampaikan sebagai berikut: 1) Kepada siswa disarankan agar lebih mempersiapkan diri dalam belajar. Kesiapan belajar yang dimiliki oleh siswa akan memberikan hasil belajar yang lebih baik, dengan memiliki kesiapan belajar siswa diharapkan dapat mengikuti dan meningkatkan hasil belajar yang diperoleh, karena kesiapan belajar memiliki korelasi yang kuat dengan kompetensi inti pengetahuan bahasa Indonesia, 2) Kepada guru alangkah baiknya agar memperhatikan kesiapan belajar siswa, karena dengan kesiapan belajar akan membuat siswa lebih aktif dalam pelajaran. Guru sebaiknya mampu mengkondisikan kesiapan belajar siswa melalui apersepsi yang dilaksanakan, 
dengan demikian siswa yang memiliki kesiapan belajar akan mampu, mengikuti pelajaran dengan baik dan aktif, karena kesiapan belajar memiliki korelasi yang kuat dengan kompetensi inti pengetahuan bahasa Indonesia, 3) Kepada kepala sekolah disarankan agar dapat menggunakan hasil penelitian ini sebagai pendukung sumber belajar guru dalam meningkatkan kualitas pembelajaran dengan memperhatikan kesiapan belajar siswa di sekolah sehingga sekolah mampu menghasilkan siswa yang berkualitas. Kepada peneliti hendaknya agar hasil penelitian ini digunakan sebagai referensi untuk melaksanakan penelitian selanjutnya dan semoga penelitian ini bermanfaat bagi seluruh elemen masyarakat yang menggunakan penelitian ini.

\section{Daftar Pustaka}

Agung, A.A.Gede. 2012. Metodologi Penelitian Pendidikan. Singaraja: Universitas Pendidikan Ganesha.

Agung, A.A.Gede. 2016. Statistik Dasar untuk Pendidikan. Yogyakarta: deepublish.

Akhadiah, Sabarti, dkk. 1991. Bahasa Indonesia I. Jakarta: Proyek Pembinaan Tenaga Kependidikan.

Arikunto, Suharsini. 2010.Prosedur Penelitian Suatu Pendekatan Praktik. Jakarta: PT. Rineka Cipta.

BSNP. 2006. Panduan Penyusunan KTSP Jenjang Pendidikan Dasar dan Menengah. Jakarta: BSNP

Budiman, Hendra. 2017. Hubungan antara Kesiapan Belajar dengan Prestasi Siswa SMK, Volume 4, Nomor1.

Dantes, N. 2017.Desain Experimen dan Analisis Data. Depok: Rajawali Pers.

Degeng, I Nyoman Sudana. 1998. Mencari Paradigma Baru Pemecahan Masalah Belajar. Malang: Departemen Pendidikan dan Kebudayaan Institut Keguruan dan Ilmu Pendidikan Malang

Djamarah, Syaiful Bahri. 2011. Psikologi Belajar. Jakarta: Rineka Cipta.

Emzir. 2011. Metodelogi Penelitian Pendidikan. Jakarta: Rajawali Pers.

Hamalik, Oemar. 2013. Kurikulum dan Pembelajaran. Jakarta: Bumi Aksara.

Kosasih, E. 2014.Strategi Belajar dan Pembelajaran Implementasi Kurikulum 2013. Bandung: Yrama Widya.

Koyan, I Wayan.2012. Statistik Teknik Analisis Data Kuantitatif. Singaraja: Universitas Pendidikan Ganesha.

Mulyani, Dessy.2013. Hubungan Kesiapan Belajar Siswa dengan Prestasi Belajar, Volume 2, Nomor 1 (hal. 27-31).

Mursyidun Nidhom, Ahmad. 2015. Hubungan Kesiapan Belajar, Lama Pembelajaran, Kesesuaian Tempat Dan Partisipasi Du/Di Dengan Hasil Prakerin Peserta Didik Kompetensi Keahlian Tkj Di Smk Kota Batu. Volume 11, Nomor 1 (hal. 1-14).

Musfiquon. 2012. Metodelogi Penelitian Pendidikan. Jakarta: PT. Prestasi Pustakaarya. 
Netra, I.B. Statistik Inferensial. 1974. Surabaya: Usaha Nasional

Permendikbud.2014. Peraturan Menteri Pendidikan dan Kebudayaan Republik Indonesia Nomor 103 tahun 2014 Tentang Implementasi Kurikulum. Jakarta: Kementerian Pendidikan dan Kebudayaan.

Permendikbud.2015. Peraturan Menteri Pendidikan dan Kebudayaan Republik Indonesia Nomor 103 tahun 2015 Tentang Implementasi Kurikulum. Jakarta: Kementerian Pendidikan dan Kebudayaan.

Sanjaya, Wina. 2013.Penelitian Pendidikan. Jakarta: Kencana.

Setyosari, H. Punaji. 2015. Metodelogi Pendidikan dan Pengembangan. Jakarta: Kencana.

Sinta B, Vivo. 2017. Pengaruh Kesiapan Belajar Terhadap Hasil Belajar Mata Pelajaran Ekonomi Kelas X Di Sma Bina Jaya Palembang.Volume 1, Nomor 1 (hal. 11-20).

Siregar, Syofian. 2015. Statistika Terapan. Jakarta: Prenadamedia Group.

Slameto. 2010. Belajar dan Fakor-Faktor Yang Mempengaruhinya.Jakarta: Rineka Cipta

Sudijono, Anas. 2005. Pengantar Evaluasi Pendidikan. Jakarta: PT Raja Grafindo Persada.

Sugiyon. 2010. Statistik untuk Penelitian. Bandung: Alfabeta.

Sugiyono. 2012a. Metode Penelitian Kuantitatif, Kualitatif Dan R\&D. Bandung: Alfabea

Sugiyono.2012b. Statistik untuk Pendidikan. Bandung: Alfabeta Bandung.

Sugiyono. 2013. Metodologi Penelitian Pendidikan. Bandung: Alfabeta.

Sugiyono. 2014. Metodologi Penelitian Pendidikan. Bandung: Alfabeta.

Sukardi.2012. Metodologi Penelitian Pendidikan. Jakarta: PT. Bumi Aksara

Supardi.2016. Aplikasi Statistika dalam Penelitian. Jakarta Selatan: Change Publication.

Susanto, Ahmad. 2013. Teori Belajar dan Pembelajaran di Sekolah Dasar. Jakarta: Kencana Prenada Media Group.

Suviana, Novita Tyas. 2012. Hubungan Kausal antara Motivasi Internal dan Kesiapan Belajar Kognitif pada Mata Pelajaran Biologi di SMA Negeri 1 Cawas Tahun Pelajaran 2011/2012, Volume 1, Nomor 1 (hal. 18-27).

Undang-undang Republik Indonesia no.20 Tahun 2003 tentang Sistem Pendidikan Nasional, 1990. Jakarta: PT. Arnas Duta Jaya.

Wirasunu, Tulus 2006.Statistik dalam Penelitian Psikologi dan Pendidikan. Malang: UMM Press. 